Click www.researchjournal.co.in/online/subdetail.html to purchase.

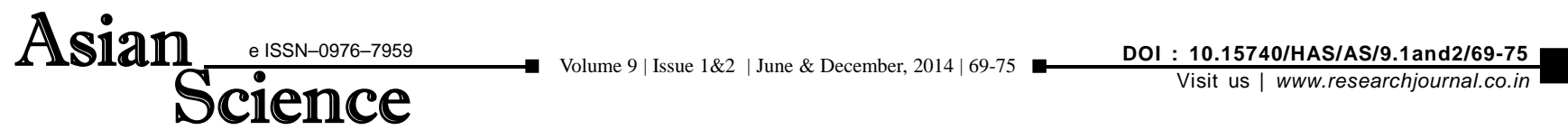

\section{A REVIEW \\ Past liberalization and future challenges of service trade}

\section{ISHITA CHATTERJEE}

Faculty of Law, University of Allahabad, ALLAHABAD (U.P.) INDIA

Key Words : Service trade, Service liberalization

View point paper : Chatterjee, Ishita (2014). Past liberalization and future challenges of service trade. Asian Sci., 9 (1\&2): 69-75. 